\title{
F10 wt Allele
}

National Cancer Institute

\section{Source}

National Cancer Institute. F10 wt Allele. NCI Thesaurus. Code C76141.

The F10 wt Allele is located in the vicinity of $13 q 34$ and is approximately $27 \mathrm{~kb}$ in length.

This allele, which encodes coagulation factor $X$ protein, plays a role in both proteolysis

and blood coagulation. Mutations in the gene are associated with factor X deficiency. 